\title{
Rевевсн Автіск: Knowledge level of beneficiary farmers of ATMQIC regarding cultivation practices of Rabi crop demonstrations in Jaipur district of Rajasthan
}

\section{- Pushpa Kumawat and Nidhi}

Article Chronicle : Received :

15.02.2020;

Revised:

06.10.2020;

Accepted :

$25 . .10 .2020$

KEY WoRds:

ATMQIC,

Knowledge,

Agriculture, Schemes,

Crop demonstrations,

Farmers, Technology fenugreek crops. Society.
SUMMARY : Agriculture Technology management Quality Improvement Center (ATMQIC)project of Rastriya Krishi Vikas Yojana was started in Shri Karan Narendra Agriculture University, Jobner to provide a 'single window'system for farmers. Keeping in view the facts the study was conducted in three selected villages of Jaipur district of Rajasthan and 120 respondent farmers were selected from these three selected villages through proportional allocation to the size of the population. The knowledge of ATMQIC beneficiary farmers was measured and found that majority of respondents (74) of ATMQIC (61.67\%) belonged to middle level of knowledge categories, followed by high $(15.83 \%)$ and low ( $22.50 \%$ ) knowledge categories of respondents of ATMQIC about rabi crop demonstrations. The Rabi crop wise findings of the study indicated that majority of respondents of ATMQIC were found to have adequate knowledge regarding cultivation techniques of Barley crop followed by wheat, mustard and

How to cite this article : Kumawat, Pushpa and Nidhi (2020). Knowledge level of beneficiary farmers of ATMQIC regarding cultivation practices of Rabi crop demonstrations in Jaipur district of Rajasthan. Agric. Update, 15(4): 428-431; DOI : 10.15740/HAS/AU/15.4/428-431. Copyright@ 2020: Hind Agri-Horticultural
Author for correspondence :

\section{Pushpa Kumawat}

Krishi Vigyan Kendra

(AU), Nagaur (Rajasthan)

India

Email:kwt1995harsh@ gmail.com

See end of the article for authors' affiliations 